\title{
Faktor risiko sarapan pagi dan makanan selingan terhadap kejadian overweight pada remaja sekolah menengah atas
}

Breakfast and snacking as risk factors of overweight in senior high school

Shelly Festilia Agusanty ${ }^{1}$, Istiti Kandarina ${ }^{2}$, I Made Alit Gunawan ${ }^{3}$

\begin{abstract}
Background: Overweight or obesity during childhood and adolescence are important risk factors for the presence of adult overweight or obesity. Eating habits in childhood and adolescence influence their healthy condition. Prospective studies of breakfast habits and nutritional status suggest an inverse (protective) association between the frequency of eating breakfast and the risk for overweight and obesity and relationships between no breakfast and increasing body weight. Objective: To examine risk factor of breakfast and snacking related to overweight status in adolescents. Method: This was observational study with case control design. First step of study was screening to have prevalence of overweight in adolescents. The second step was case control study participated by 100 overweight adolescents and 100 normal weight adolescents in senior high school matched in sex, age and school. Data collected were weight and height measurements for nutritional status, respondent identity and characteristic, breakfast dan snacking habits and physical activity. Statistical analysis used Chi-Square statistics and multivariable logistic regression analysis. Results: Prevalence of overweight in adolescents were 16,8\%. There were significant association between breakfast with overweight ( $p<0,05 ;$ OR $=3.1 ; 95 \%$ CI=1.4-7.47). There was no association between snacking and overweight, but there were significant association between frequency of snacking $(O R=1.9 ; 95 \%$ CI=1.05-3.50), energy of snacking $(O R=2.1 ; 95 \% C I=1.13-4.02)$, and carbohydrate of snacking $(O R=4.5 ; 95 \% C I=1.94-11.50)$ with overweight. In multivariate model, breakfast habits, carbohydrate of snacking and physical activity had significant association with overweight. Conclusion: Skipping breakfast was a risk factor for overweight in adolescence. Adolescents who had snacking more than twice a day were having greater risk factor for overweight.
\end{abstract}

KEY WORDS: breakfast, snacking, overweight

\begin{abstract}
ABSTRAK
Latar belakang: Overweight dan obesitas pada masa anak dan remaja mempengaruhi kejadian overweight dan obesitas pada masa dewasa. Pola dan perilaku makan pada anak dan remaja mempengaruhi kesehatannya. Beberapa penelitian tentang hubungan antara perilaku sarapan dan status gizi menunjukkan bahwa dengan meningkatnya frekuensi sarapan pagi dapat menurunkan risiko overweight dan obesitas serta ada hubungan antara tidak sarapan pagi dengan meningkatnya berat badan. Tujuan: Mengetahui faktor risiko sarapan pagi dan makanan selingan terhadap kejadian overweight pada remaja SMA. Metode: Jenis penelitian observasional dengan rancangan kasus kontrol. Tahap awal dilakukan skrining untuk mengetahui prevalensi overweight pada remaja. Jumlah subjek pada kelompok kasus sebanyak 100 remaja SMA yang overweight dan kontrol sebanyak 100 remaja SMA yang tidak overweight dengan jenis kelamin, umur, dan asal sekolah yang sama. Data yang dikumpulkan berupa karakteristik subjek, berat badan dan tinggi badan untuk mengukur status gizi, pola konsumsi sarapan pagi dan makanan selingan serta aktivitas fisik. Data dianalisis menggunakan uji Chi-Square dan uji regresi logistik. Hasil: Prevalensi overweight kelompok remaja pada penelitian ini sebesar 16,8\%. Sarapan pagi dan kejadian overweight menunjukkan hubungan bermakna ( $<<0,05 ; \mathrm{OR}=3,1 ; 95 \% \mathrm{CI}=1,4-7,47)$. Sebaliknya, makanan selingan tidak berhubungan dengan kejadian overweight, tetapi ada hubungan antara frekuensi makanan selingan $(\mathrm{OR}=1,9 ; 95 \% \mathrm{CI}=1,05-3,50)$, energi makanan selingan $(\mathrm{OR}=2,1 ; 95 \% \mathrm{CI}=1,13-4,02)$, dan karbohidrat makanan selingan $(\mathrm{OR}=4,5 ; 95 \% \mathrm{CI}=1,94-11,50)$ dengan kejadian overweight. Analisis multivariat menunjukkan bahwa sarapan pagi, karbohidrat makanan selingan, dan aktivitas merupakan variabel yang berhubungan dengan kejadian overweight. Simpulan: Remaja yang tidak rutin sarapan pagi berisiko menjadi overweight dibandingkan remaja yang rutin sarapan pagi. Remaja yang mengonsumsi makanan selingan lebih dari dua kali dalam sehari berisiko menjadi overweight dibandingkan remaja yang mengonsumsi makanan selingan dua kali atau kurang dalam sehari.
\end{abstract}

KATA KUNCI: sarapan pagi, makanan selingan, overweight

\footnotetext{
Korespondensi: Jurusan Gizi, Politeknik Kesehatan Kementerian Kesehatan Pontianak, Jl. 28 Oktober Siantan Hulu Pontianak, Kalimantan Barat, e-mail: shellymahira@yahoo.co.id

2 Program Studi S2 Ilmu Kesehatan Masyarakat, Fakultas Kedokteran Universitas Gadjah Mada, J1. Farmako, Sekip Utara, Yogyakarta 55281, e-mail: ikandarina@yahoo.com

3 Jurusan Gizi, Politeknik Kesehatan Kementerian Kesehatan Yogyakarta, Jl. Tata Bumi No. 3 Banyuraden Gamping, Sleman, Yogyakarta
} 


\section{PENDAHULUAN}

Berat badan lebih (overweight) dan obesitas merupakan masalah kesehatan masyarakat yang perlu mendapatkan perhatian serius karena merupakan peringkat kelima penyebab kematian di dunia. Tidak kurang 2,8 juta orang dewasa meninggal setiap tahunnya disebabkan oleh overweight dan obesitas (1). Prevalensi overweight atau gizi lebih di Indonesia mengalami peningkatan setiap tahunnya. Menurut data Riset Kesehatan Dasar (Riskesdas), pada tahun 2007 prevalensi overweight kelompok usia 15 tahun ke atas sebesar 19,1\% dan pada tahun 2010 prevalensi gizi lebih pada kelompok usia 13-15 tahun sebesar 2,5\%; kelompok usia 16-18 tahun sebesar 1,4\%; serta prevalensi overweight pada kelompok usia dewasa ( $>18$ tahun) sebesar $10 \%$ dan obes $11,7 \%$. Prevalensi gizi lebih di Kalimantan Barat pada kelompok usia 15 tahun ke atas berdasarkan Riskesdas 2007 yaitu sebesar 13\%. Sementara menurut data Riskesdas tahun 2010 menunjukkan prevalensi gizi lebih untuk kelompok usia 13-15 tahun sebesar 1,5\% dan kelompok usia 16-18 tahun sebesar $0,7 \%$ sedangkan prevalensi overweight pada kelompok usia di atas 18 tahun sebesar 8,6\% dan obes $9,5 \%(2,3)$.

Overweight dan obesitas pada masa anak dan remaja mempengaruhi kejadian obesitas pada masa dewasa (4). Overweight dan obesitas pada masa remaja juga berpengaruh terhadap timbulnya beberapa penyakit degeneratif saat dewasa. Penelitian pada anak sekolah yang overweight menunjukkan bahwa 58\% mempunyai sedikitnya satu faktor risiko penyakit kardiovaskuler dan 50\% mempunyai dua faktor risiko (5). Overweight pada anak dan remaja dipengaruhi oleh interaksi kompleks antara faktor genetik dan faktor lingkungan (6). Selain itu, remaja telah dapat menentukan makanan yang diinginkannya dan seringkali menjalani pola makan yang salah seperti tidak sarapan pagi, lebih memilih mengonsumsi makanan cepat saji, dan sering mengonsumsi makanan di luar rumah. Kebiasaan ini menyebabkan remaja mengonsumsi makanan padat energi dan rendah nilai gizi yang berpotensi timbulnya overweight (7).

Beberapa penelitian menunjukkan hubungan antara sarapan pagi dengan status gizi anak sekolah. Penelitian pada anak usia 5-6 tahun di Selandia Baru menunjukkan bahwa anak yang tidak sarapan pagi mengakibatkan kenaikan indeks massa tubuh (IMT) (8). Data studi cross sectional pada anak dan dewasa menunjukkan bahwa ada hubungan antara tidak sarapan pagi dengan overweight dan gejala resistensi insulin (9). Beberapa penelitian sebelumnya tentang hubungan antara perilaku sarapan dan status gizi menunjukkan bahwa dengan meningkatnya frekuensi sarapan pagi dapat menurunkan risiko overweight dan tidak sarapan pagi berhubungan dengan meningkatnya berat badan (10). Oleh karena itu, tujuan penelitian ini adalah untuk mengetahui faktor risiko sarapan pagi dan makanan selingan dengan kejadian overweight pada remaja sekolah menengah atas (SMA) di Kota Pontianak.

\section{BAHAN DAN METODE}

Penelitian ini adalah penelitian observasional dengan rancangan penelitian kasus kontrol. Penelitian dilakukan di Kota Pontianak dengan waktu penelitian selama 3 bulan yaitu bulan Februari sampai Mei 2013. Kasus adalah remaja SMA di Kota Pontianak yang mengalami overweight (IMT/U $\geq$ persentil ke-85) yang terdeteksi saat survei sedangkan kelompok kontrol adalah remaja SMA yang tidak mengalami overweight dan berstatus gizi baik yang mempunyai jenis kelamin, umur, dan asal sekolah yang sama dengan kasus. Tahap awal penelitian adalah melakukan skrining pada sekolah yang terpilih menjadi tempat penelitian untuk mengetahui prevalensi overweight pada remaja. Selanjutnya, remaja yang terpilih menjadi responden akan ditelusuri secara retrospektif pola makannya yang meliputi sarapan pagi dan makanan selingan.

Populasi penelitian ini adalah seluruh remaja SMA baik negeri maupun swasta di Kota Pontianak dan untuk mengetahui prevalensi overweight pada remaja SMA di Kota Pontianak maka dilakukan skrining dengan metode stratified random sampling. Subjek penelitian merupakan sebagian dari populasi dan diambil berdasarkan proportional stratified random sampling dari hasil skrining remaja overweight pada sekolah yang terpilih. Besar subjek penelitian dihitung berdasarkan perhitungan besar sampel untuk rancangan kasus kontrol (11) dengan nilai prevalensi sarapan pagi pada anak 
obesitas berdasarkan penelitian sebelumnya sebesar 0,44 dan prevalensi sarapan pagi pada anak yang tidak obesitas sebesar 0,637 (12); tingkat kepercayaan 95\% $\left(\mathrm{Z}_{1-\alpha}=1,96 ; \mathrm{Z}_{1-\beta}=0,842\right)$; serta kekuatan penelitian sebesar $80 \%$ sehingga jumlah sampel minimal yang dibutuhkan untuk kasus kontrol adalah masing-masing sebanyak 95 orang.

Subjek yang terpilih berjumlah 100 orang kasus dan 100 orang kontrol dengan kriteria inklusi kasus adalah remaja SMA berumur 16-18 tahun yang overweight, bersedia menjadi sampel penelitian, dan tidak dalam keadaan sakit saat penelitian dilakukan sedangkan kriteria inklusi kontrol adalah remaja SMA berumur 16-18 tahun yang tidak overweight, bersedia menjadi sampel penelitian, dan tidak dalam keadaan sakit saat penelitian dilakukan. Kriteria eksklusi kasus dan kontrol yaitu subjek menjalani program diit penurunan berat badan dan mengonsumsi obat-obatan. Pemilihan kasus dan kontrol dilakukan matching terhadap umur, jenis kelamin, dan asal sekolah.

Variabel dalam penelitian ini terdiri dari variabel terikat yaitu overweight dan variabel bebas yaitu sarapan pagi, jumlah asupan energi dari sarapan pagi, jumlah asupan protein dari sarapan pagi, jumlah asupan lemak dari sarapan pagi, jumlah asupan karbohidrat dari sarapan pagi, makanan selingan, frekuensi makanan selingan, jumlah asupan energi dari makanan selingan, jumlah asupan protein dari makanan selingan, jumlah asupan lemak dari makanan selingan, dan jumlah asupan karbohidrat dari makanan selingan. Variabel luar adalah asupan energi makanan utama dan aktivitas fisik. Data pola konsumsi sarapan pagi dan makanan selingan diperoleh dengan melakukan wawancara menggunakan kuesioner semi quantitative food frequency questionnaire (SQFFQ) yang memuat frekuensi dan jenis konsumsi sarapan pagi dan makanan selingan. Kuesioner SQFFQ yang digunakan dalam penelitian ini merupakan modifikasi dari kuesioner penelitian sebelumya (13). Jumlah asupan energi, protein, lemak, karbohidrat dari sarapan pagi dan makanan selingan diperoleh dengan menggunakan food recall 24 jam selama 4 hari tidak berturut-turut meliputi 2 hari biasa dan 2 hari libur. Aktivitas fisik diperoleh dengan menggunakan kuesioner international physical activity questionnaire (IPAQ) yang telah dimodifikasi.
Overweight diketahui berdasarkan pengukuran IMT (berat badan dalam kilogram dibagi dengan kuadrat tinggi badan dalam meter) yaitu apabila IMT sama dengan persentil ke-85 atau lebih dari baku rujukan World Health Organization (WHO) 2007 sedangkan dikategorikan tidak overweight apabila IMT lebih dari persentil ke-5 dan kurang dari persentil ke85 dari baku rujukan (14). Data berat badan diperoleh melalui pengukuran berat badan menggunakan timbangan injak digital dengan ketelitian $0,1 \mathrm{~kg}$ dan data tinggi badan diperoleh dengan mengukur tinggi badan menggunakan microtoise. Sarapan pagi adalah makanan dan minuman yang dikonsumsi di pagi hari setelah bangun tidur sebelum memulai aktivitas seharihari dan dilakukan tidak melebihi dari jam 10 pagi (10) yang dikategorikan rutin apabila mengonsumsi sarapan pagi setiap hari ( 7 kali seminggu) dan tidak rutin apabila mengonsumsi sarapan pagi tidak setiap hari (0-6 kali seminggu). Sementara itu, makanan selingan adalah makanan dan minuman yang dikonsumsi di antara makanan utama (sarapan pagi, makan siang, dan makan malam) termasuk minuman susu, soft drink, sport drink, dan minuman berenergi (15). Sarapan pagi harus memenuhi sebanyak $20-25 \%$ dari kebutuhan kalori sehari (16) demikian juga dengan makanan selingan menyumbang $20-25 \%$ dari total kebutuhan sehari (7).

Berdasarkan angka kecukupan gizi (AKG) maka kebutuhan energi untuk sarapan pagi dan makanan selingan masing-masing sebesar 520-650 kkal untuk remaja laki-laki dan 440-550 kkal untuk remaja perempuan serta dikategorikan tinggi apabila jumlah asupan lebih dari 650 kkal (laki-laki) atau 550 kkal (perempuan) untuk konsumsi dalam satu hari. Kebutuhan protein untuk sarapan pagi sebesar $12-15 \%$ dari jumlah asupan energi sarapan pagi dan dikategorikan tinggi apabila jumlah asupan protein lebih dari 24,4 g (laki-laki) atau 20,6 g (perempuan). Kebutuhan lemak untuk sarapan pagi sebesar $15-25 \%$ dari jumlah asupan energi sarapan pagi dengan kategori tinggi apabila jumlah asupan lemak lebih dari $18,1 \mathrm{~g}$ (laki-laki) atau 15,3 g (perempuan). Demikian juga untuk kategori pada jumlah asupan protein dan lemak dari makanan selingan. Sementara itu, kebutuhan 
karbohidrat untuk sarapan pagi sebesar $60-68 \%$ dari jumlah asupan energi sarapan pagi yang dikategorikan tinggi apabila jumlah asupan karbohidrat lebih dari 110,5 $\mathrm{g}$ (laki-laki) atau 93,5 g (perempuan) sedangkan asupan karbohidrat dari makanan selingan dikategorikan tinggi apabila asupan lebih dari 105,6 g (laki-laki) atau 89,4 g (perempuan) $(7,16,17)$.

Asupan energi makanan utama diperoleh dari konsumsi makanan utama (makan siang dan makan malam) selain sarapan pagi dan makanan selingan. Sarapan pagi harus memenuhi sebanyak 20-25\% dari kebutuhan kalori sehari sedangkan makanan selingan menyumbang 20-25\% dari total kebutuhan sehari sehingga kebutuhan energi dari makan utama sebesar $50-60 \%$ dari kebutuhan energi total dalam sehari $(7,16)$. Asupan energi makanan utama dikategorikan tinggi jika jumlah asupan energi lebih dari 60\% AKG. Lebih lanjut, variabel luar berupa aktivitas fisik diukur dalam menit dan dinyatakan dalam metabolic energy turnover (METs) kemudian dibedakan menjadi tiga parameter yaitu berat (jumlah nilai IPAQ $>3000$ METs), sedang (jumlah nilai IPAQ $=600-3000$ METs), dan ringan (jumlah nilai IPAQ $<600$ METs).

Pengambilan data dibantu oleh tenaga enumerator lulusan D3 Jurusan Gizi yang sudah diberikan arahan dan penjelasan. Persamaan persepsi antara peneliti dan enumerator diketahui melalui uji interrater reliability menggunakan uji statistik Kappa dengan gold standard adalah peneliti dan hasil ujinya berkisar antara 81,25 - 93,75\%. Pengolahan data menggunakan program STATA sedangkan data asupan gizi diolah menggunakan nutrisurvey. Data dianalisis secara kuantitatif meliputi analisis univariat, bivariat, dan multivariat. Analisis univariat ini digunakan untuk mengetahui karakteristik subjek penelitian, prevalensi overweight, status overweight subjek, pola konsumsi sarapan pagi, pola konsumsi makanan selingan, asupan makan sehari, dan aktivitas fisik remaja. Analisis bivariat untuk mengetahui faktor risiko dari setiap variabel terhadap kejadian overweight. Analisis multivariat untuk mengetahui variabel yang paling besar berpengaruh terhadap kejadian overweight. Penelitian ini telah memperoleh ethical clearance dengan nomor KE/FK/22/EC dari Komisi Etik Fakultas Kedokteran Universitas Gadjah Mada.

\section{HASIL}

Sebanyak 6 sekolah yang terpilih terdiri dari 2 sekolah negeri dan 4 sekolah swasta. Seluruh remaja dari sekolah yang terpilih diukur berat badan dan tinggi badannya untuk mengetahui status gizinya. Hasil skrining diperoleh prevalensi overweight sebesar 16,8\% atau sebanyak 432 siswa dari 2573 siswa yang diukur status gizinya. Subjek penelitian berjumlah 200 siswa remaja terdiri dari 100 siswa overweight dan 100 siswa yang tidak overweight. Selanjutnya, setelah dilakukan matching maka subjek penelitian terdiri dari 50 kasus dan 50 kontrol dengan jenis kelamin laki-laki serta 50 kasus dan 50 kontrol dengan jenis kelamin perempuan.

Tidak ada perbedaan yang bermakna pada karakteristik subjek penelitian untuk usia ibu dan ayah, tingkat pendidikan ibu dan ayah, status overweight ibu dan ayah, serta uang saku antara kelompok overweight dan kelompok tidak overweight. Sementara itu, pekerjaan ibu ternyata berhubungan bermakna dengan kejadian

Tabel 1. Karakteristik subjek penelitian

\begin{tabular}{|c|c|c|c|c|c|}
\hline \multirow{2}{*}{ Variabel } & \multicolumn{2}{|c|}{ Overweight } & \multicolumn{2}{|c|}{$\begin{array}{c}\text { Tidak } \\
\text { overweight }\end{array}$} & \multirow[t]{2}{*}{$\mathbf{p}$} \\
\hline & n & $\%$ & $\mathbf{n}$ & $\%$ & \\
\hline \multicolumn{6}{|l|}{ Usia ibu (tahun) } \\
\hline$>50$ & 5 & 5 & 8 & 8 & 0,300 \\
\hline$\leq 50$ & 95 & 95 & 92 & 92 & \\
\hline \multicolumn{6}{|l|}{ Usia ayah (tahun) } \\
\hline$>50$ & 25 & 25 & 22 & 22 & 0,610 \\
\hline$\leq 50$ & 75 & 75 & 78 & 78 & \\
\hline \multicolumn{6}{|l|}{ Tingkat pendidikan ibu } \\
\hline Tidak tinggi & 68 & 68 & 73 & 73 & 0,430 \\
\hline Tinggi & 32 & 32 & 27 & 27 & \\
\hline \multicolumn{6}{|c|}{ Tingkat pendidikan ayah } \\
\hline Tidak tinggi & 55 & 55 & 61 & 61 & 0,390 \\
\hline Tinggi & 45 & 45 & 39 & 39 & \\
\hline \multicolumn{6}{|l|}{ Pekerjaan ibu } \\
\hline Bekerja & 60 & 60 & 43 & 43 & $0,016^{*}$ \\
\hline Tidak bekerja & 40 & 40 & 57 & 57 & \\
\hline \multicolumn{6}{|l|}{ Status overweight ibu } \\
\hline Overweight & 42 & 42 & 35 & 35 & 0,310 \\
\hline Tidak overweight & 58 & 58 & 65 & 65 & \\
\hline \multicolumn{6}{|l|}{ Status overweight ayah } \\
\hline Overweight & 44 & 44 & 37 & 37 & 0,310 \\
\hline Tidak overweight & 56 & 56 & 63 & 63 & \\
\hline \multicolumn{6}{|l|}{ Uang saku } \\
\hline$>$ rata-rata & 28 & 28 & 38 & 38 & 0,130 \\
\hline$\leq$ rata-rata & 72 & 72 & 62 & 62 & \\
\hline
\end{tabular}

Keterangan: * = bemakna (nilai $\mathrm{p}<0,05$ ) 
Shelly Festilia Agusanty, dkk: Faktor risiko sarapan pagi dan makanan selingan terhadap kejadian overweight

Tabel 2. Hubungan sarapan pagi dengan kejadian overweight pada remaja

\begin{tabular}{|c|c|c|c|c|c|c|}
\hline \multirow{2}{*}{ Variabel } & \multicolumn{2}{|c|}{ Overweight } & \multicolumn{2}{|c|}{ Tidak overweight } & \multirow{2}{*}{$\begin{array}{c}\text { OR } \\
(95 \% \mathrm{CI})\end{array}$} & \multirow[b]{2}{*}{$\mathbf{p}$} \\
\hline & $\mathrm{n}$ & $\%$ & $\mathbf{n}$ & $\%$ & & \\
\hline \multicolumn{7}{|l|}{ Sarapan pagi } \\
\hline Tidak rutin & 89 & 89 & 72 & 72 & 3,1 & $0,02^{*}$ \\
\hline Rutin & 11 & 11 & 28 & 28 & $(1,40-7,47)$ & \\
\hline \multicolumn{7}{|l|}{ Energi sarapan pagi } \\
\hline Tinggi & 9 & 9 & 7 & 7 & 1,3 & 0,60 \\
\hline Tidak tinggi & 91 & 91 & 93 & 93 & $(0,41-4,33)$ & \\
\hline \multicolumn{7}{|l|}{ Protein sarapan pagi } \\
\hline Tinggi & 5 & 5 & 5 & 5 & 1,0 & 1,00 \\
\hline Tidak tinggi & 95 & 95 & 95 & 95 & $(0,22-4,50)$ & \\
\hline \multicolumn{7}{|l|}{ Lemak sarapan pagi } \\
\hline Tinggi & 25 & 25 & 27 & 27 & 0,9 & 0,75 \\
\hline Tidak tinggi & 75 & 75 & 72 & 72 & $(0,46-1,80)$ & \\
\hline \multicolumn{7}{|c|}{ Karbohidrat sarapan pagi } \\
\hline Tinggi & 6 & 6 & 7 & 7 & 0,8 & 0,77 \\
\hline Tidak tinggi & 94 & 94 & 93 & 93 & $(0,22-3,07)$ & \\
\hline
\end{tabular}

Keterangan: * = bemakna (nilai $\mathrm{p}<0,05$ )

overweight $(\mathrm{p}<0,05)$ (Tabel 1). Ibu yang bekerja jumlahnya paling banyak ditemukan pada kelompok overweight $(60 \%)$ dibandingkan kelompok tidak overweight (43\%). Salah satu faktor yang dapat dikaitkan antara pekerjaan ibu dengan kejadian overweight adalah faktor ekonomi. Status ibu yang juga bekerja selain ayah cenderung berpengaruh terhadap peningkatan ekonomi keluarga. Peningkatan ekonomi mempermudah seseorang untuk memperoleh makanan yang tinggi energi, ketersediaan pangan yang cukup, dan meningkatkan gaya hidup sedentari (sedentary lifestyle) (18). Sebagian besar subjek mendapatkan uang saku dari orang tua dalam jangka waktu harian. Kelompok overweight maupun kelompok tidak overweight, sebagian besar mempergunakan uang saku untuk membeli makanan dan minuman.

Hasil penelitian menunjukkan adanya hubungan sarapan pagi dengan kejadian overweight $(\mathrm{p}<0,05)$. Remaja yang tidak rutin sarapan pagi mempunyai risiko menjadi overweight sebesar 3,1 kali $(95 \% \mathrm{CI}=1,40-7,47)$ dibandingkan remaja yang rutin sarapan pagi. Namun, energi, protein, lemak, dan karbohidrat dari sarapan pagi tidak menunjukkan hubungan dengan kejadian overweight (Tabel 2). Berdasarkan hasil wawancara menggunakan SQFFQ diperoleh jenis makanan yang sering dikonsumsi subjek untuk sarapan pagi dan makanan selingan. Berdasarkan besar frekuensinya, lima peringkat teratas jenis makanan yang paling sering dikonsumsi untuk sarapan pagi pada kelompok overweight adalah nasi putih, mi instan, telur, nasi goreng, dan ayam goreng sedangkan pada kelompok tidak overweight adalah susu, nasi putih, roti, mi instan, dan telur.

Tabel 3 menunjukkan gambaran asupan gizi sarapan pagi pada kelompok overweight dan tidak overweight. Kelompok remaja yang rutin sarapan pagi, menunjukkan hubungan bermakna antara asupan energi sarapan pagi dengan kejadian overweight yaitu remaja dengan asupan energi sarapan pagi yang tinggi berisiko 6,9 kali (95\% $\mathrm{CI}=1,3-37,5)$ menjadi overweight dibandingkan remaja dengan asupan energi sarapan pagi yang tidak tinggi.

Selain itu, kelompok remaja yang rutin sarapan pagi juga menunjukkan hubungan bermakna pada asupan lemak dan asupan karbohidrat dari sarapan pagi dengan kejadian overweight. Remaja dengan asupan lemak yang tinggi berisiko 8 kali $(95 \% \mathrm{CI}=1,7-38,8)$ menjadi overweight dibandingkan remaja dengan asupan lemak yang tidak tinggi. Sementara itu, remaja dengan asupan karbohidrat tinggi berisiko 7,5 kali $(95 \% \mathrm{CI}=1,1-49,2)$ menjadi overweight dibandingkan remaja dengan asupan karbohidrat yang tidak tinggi.

Hasil penelitian tidak menunjukkan hubungan yang bermakna antara konsumsi makanan selingan dengan kejadian overweight $(\mathrm{p}>0,05)$. Demikian juga hubungan antara protein dan lemak makanan selingan dengan kejadian overweight yang tidak menunjukkan 
Shelly Festilia Agusanty, dkk: Faktor risiko sarapan pagi dan makanan selingan terhadap kejadian overweight

Tabel 3. Asupan zat gizi sarapan pagi pada kelompok overweight dan tidak overweight berdasarkan rutinitas sarapan pagi remaja

\begin{tabular}{|c|c|c|c|c|c|c|c|}
\hline \multirow{2}{*}{ Sarapan pagi } & \multirow{2}{*}{$\begin{array}{l}\text { Asupan gizi } \\
\text { sarapan pagi }\end{array}$} & \multicolumn{2}{|c|}{ Overweight } & \multicolumn{2}{|c|}{ Tidak overweight } & \multirow{2}{*}{$\mathbf{p}$} & \multirow{2}{*}{$\begin{array}{c}\text { OR } \\
(95 \% \mathrm{CI}) \\
\end{array}$} \\
\hline & & n & $\%$ & $\mathbf{n}$ & $\%$ & & \\
\hline \multirow[t]{2}{*}{ Tidak rutin } & Energi tinggi & 4 & 4,5 & 4 & 5,6 & \multirow{2}{*}{1,00} & 0,8 \\
\hline & Energi tidak tinggi & 85 & 95,5 & 68 & 94,4 & & $(0,2-3,3)$ \\
\hline \multirow[t]{2}{*}{ Rutin } & Energi tinggi & 5 & 45,5 & 3 & 10,7 & \multirow{2}{*}{$0,03^{*}$} & \\
\hline & Energi tidak tinggi & 6 & 54,5 & 25 & 89,3 & & $(1,3-37,5)$ \\
\hline \multirow[t]{2}{*}{ Tidak rutin } & Protein tinggi & 2 & 2,2 & 4 & 5,6 & \multirow{2}{*}{0,40} & \\
\hline & Protein tidak tinggi & 87 & 97,8 & 68 & 94,4 & & $(0,1-2,1)$ \\
\hline \multirow[t]{2}{*}{ Rutin } & Protein tinggi & 3 & 27,3 & 1 & 3,6 & \multirow{2}{*}{0,06} & \\
\hline & Protein tidak tinggi & 8 & 72,7 & 27 & 96,4 & & $(0,9-111,2)$ \\
\hline \multirow[t]{2}{*}{ Tidak rutin } & Lemak tinggi & 17 & 19,1 & 20 & 27,8 & \multirow{2}{*}{0,26} & \\
\hline & Lemak tidak tinggi & 72 & 80,9 & 52 & 72,2 & & $(0,3-1,3)$ \\
\hline \multirow[t]{2}{*}{ Rutin } & Lemak tinggi & 8 & 72,7 & 7 & 25,0 & \multirow{2}{*}{$0,01^{*}$} & \\
\hline & Lemak tidak tinggi & 3 & 27,3 & 21 & 75,0 & & $(1,7-38,8)$ \\
\hline \multirow[t]{2}{*}{ Tidak rutin } & $\mathrm{KH}$ tinggi & 2 & 2,2 & 5 & 6,9 & \multirow{2}{*}{0,24} & 0,3 \\
\hline & $\mathrm{KH}$ tidak tinggi & 87 & 97,8 & 67 & 93,1 & & $(0,06-1,63)$ \\
\hline \multirow[t]{2}{*}{ Rutin } & $\mathrm{KH}$ tinggi & 4 & 36,4 & 2 & 7,1 & \multirow{2}{*}{$0,04^{*}$} & 7,5 \\
\hline & $\mathrm{KH}$ tidak tinggi & 7 & 63,6 & 26 & 92,9 & & $(1,1-49,2)$ \\
\hline
\end{tabular}

Keterangan: $\mathrm{KH}=$ karbohidrat; ${ }^{*}=$ bemakna $($ nilai $\mathrm{p}<0,05)$

hubungan bermakna. Namun, terdapat hubungan antara frekuensi makanan selingan, energi makanan selingan, dan karbohidrat makanan selingan dengan kejadian overweight $(\mathrm{p}<0,05)$ (Tabel 4). Berdasarkan besar frekuensi jenis makanan selingan yang dikonsumsi subjek, lima peringkat teratas jenis makanan selingan yang paling sering dikonsumsi oleh remaja kelompok overweight adalah mi instan, bakwan, permen, nasi goreng, dan coklat sedangkan kelompok tidak overweight adalah bakwan, mi instan, permen, pisang goreng, dan tahu goreng.

Jumlah remaja yang mengonsumsi makanan selingan lebih banyak dibandingkan remaja yang tidak mengonsumsi makanan selingan, baik pada kelompok overweight maupun tidak overweight dengan persentase terbesar pada kelompok overweight (94\%). Remaja yang mengonsumsi makanan selingan lebih dari 2 kali dalam sehari berisiko 1,9 kali $(95 \% \mathrm{CI}=1,05-3,50)$ menjadi overweight dibandingkan remaja yang mengonsumsi makanan selingan kurang atau sama dengan 2 kali sehari. Selain itu, remaja dengan energi makanan selingan yang tinggi berisiko 2,1 kali $(95 \% \mathrm{CI}=1,13-4,02)$ menjadi overweight dibandingkan remaja dengan energi makanan selingan yang tidak tinggi. Demikian juga karbohidrat makanan selingan yang tinggi berisiko 4,5 kali (95\% CI: 1,94-11,50) terhadap kejadian overweight dibandingkan karbohidrat makanan selingan yang tidak tinggi.

Hasil penelitian menunjukkan asupan energi makanan utama tidak berhubungan bermakna dengan kejadian overweight, demikian juga dengan asupan protein, lemak, dan karbohidrat makanan utama. Sebaliknya, tingkat aktivitas fisik mempunyai hubungan yang bermakna dengan kejadian overweight pada remaja (Tabel 5). Hal ini menunjukkan bahwa remaja overweight (65\%) lebih banyak yang mempunyai aktivitas ringan dibandingkan remaja yang tidak overweight (43\%). Kurangnya beraktivitas dan asupan makanan yang tidak seimbang telah diketahui sebagai penyebab utama meningkatnya berat badan (19). Beberapa penelitian menunjukkan bahwa perilaku kurang gerak (sedentary behaviours) seperti menonton televisi dan bermain komputer berhubungan dengan meningkatnya prevalensi obesitas (20).

Berdasarkan Tabel 6, setelah dilakukan uji multivariat maka variabel yang berhubungan bermakna terhadap kejadian overweight adalah variabel sarapan pagi, karbohidrat makanan selingan, dan aktivitas fisik. Model 1 untuk mengetahui hubungan variabel sarapan pagi, 
Shelly Festilia Agusanty, dkk: Faktor risiko sarapan pagi dan makanan selingan terhadap kejadian overweight

Tabel 4. Hubungan makanan selingan dengan kejadian overweight pada remaja

\begin{tabular}{|c|c|c|c|c|c|c|}
\hline \multirow{2}{*}{ Variabel } & \multicolumn{2}{|c|}{ Overweight } & \multicolumn{2}{|c|}{ Tidak overweight } & \multirow{2}{*}{$\begin{array}{c}\text { OR } \\
(95 \% \mathrm{CI})\end{array}$} & \multirow[b]{2}{*}{$\mathbf{p}$} \\
\hline & $n$ & $\%$ & $\mathbf{n}$ & $\%$ & & \\
\hline \multicolumn{7}{|l|}{ Makanan Selingan } \\
\hline Ya & 94 & 94 & 90 & 90 & 1,7 & 0,300 \\
\hline Tidak & 6 & 6 & 10 & 10 & $(0,55-6,06)$ & \\
\hline \multicolumn{7}{|c|}{ Frekuensi makanan selingan } \\
\hline$>2$ kali & 62 & 62 & 46 & 46 & 1,9 & $0,023^{*}$ \\
\hline$\leq 2$ kali & 38 & 38 & 54 & 54 & $(1,05-3,50)$ & \\
\hline \multicolumn{7}{|c|}{ Energi makanan selingan } \\
\hline Tinggi & 44 & 44 & 27 & 27 & 2,1 & $0,012^{*}$ \\
\hline Tidak tinggi & 56 & 56 & 73 & 73 & $(1,13-4,02)$ & \\
\hline \multicolumn{7}{|c|}{ Protein makanan selingan } \\
\hline Tinggi & 11 & 11 & 11 & 11 & 1,0 & 1,000 \\
\hline Tidak tinggi & 89 & 89 & 89 & 89 & $(0,37-2,69)$ & \\
\hline \multicolumn{7}{|c|}{ Lemak makanan selingan } \\
\hline Tinggi & 59 & 59 & 60 & 60 & 0,96 & 0,890 \\
\hline Tidak tinggi & 41 & 41 & 40 & 40 & $(0,52-1,75)$ & \\
\hline \multicolumn{7}{|l|}{ KH makanan selingan } \\
\hline Tinggi & 31 & 31 & 9 & 9 & 4,5 & $0,000^{*}$ \\
\hline Tidak tinggi & 69 & 69 & 91 & 91 & $(1,94-11,50)$ & \\
\hline
\end{tabular}

Keterangan: $\mathrm{KH}=$ karbohidrat; ${ }^{*}=$ bemakna (nilai $\left.\mathrm{p}<0,05\right)$

Tabel 5. Hubungan asupan zat gizi makanan utama dan aktivitas fisik dengan kejadian overweight pada remaja

\begin{tabular}{|c|c|c|c|c|c|c|}
\hline \multirow{2}{*}{ Variabel } & \multicolumn{2}{|c|}{ Overweight } & \multicolumn{2}{|c|}{ Tidak overweight } & \multirow{2}{*}{$\begin{array}{c}\text { OR } \\
(95 \% \text { CI })\end{array}$} & \multirow{2}{*}{$\mathbf{p}$} \\
\hline & $\mathbf{n}$ & $\%$ & $\mathbf{n}$ & $\%$ & & \\
\hline \multicolumn{7}{|l|}{ Energi makan utama } \\
\hline Tinggi & 37 & 37 & 27 & 27 & \multirow{2}{*}{$\begin{array}{c}1,59 \\
(0,83-3,02)\end{array}$} & \multirow[t]{2}{*}{0,130} \\
\hline Tidak tinggi & 63 & 63 & 73 & 73 & & \\
\hline \multicolumn{7}{|c|}{ Protein makan utama } \\
\hline Tinggi & 2 & 2 & 1 & 1 & 2,02 & \multirow[t]{2}{*}{0,560} \\
\hline Tidak tinggi & 98 & 98 & 99 & 99 & $(0,10-22,6)$ & \\
\hline \multicolumn{7}{|c|}{ Lemak makan utama } \\
\hline Tinggi & 9 & 9 & 6 & 6 & 1,5 & \multirow[t]{2}{*}{0,420} \\
\hline Tidak tinggi & 91 & 91 & 94 & 94 & $(0,47-5,5)$ & \\
\hline \multicolumn{7}{|l|}{ KH makan utama } \\
\hline Tinggi & 45 & 45 & 34 & 34 & 1,5 & \multirow[t]{2}{*}{0,110} \\
\hline Tidak tinggi & 55 & 55 & 66 & 66 & $(0,86-2,92)$ & \\
\hline \multicolumn{5}{|l|}{ Aktivitas fisik } & \multirow{3}{*}{$\begin{array}{c}2,46 \\
(1,33-4,54)\end{array}$} & \multirow{3}{*}{$0,002^{*}$} \\
\hline Ringan & 65 & 65 & 43 & 43 & & \\
\hline Sedang & 35 & 35 & 57 & 57 & & \\
\hline
\end{tabular}

Keterangan: ${ }^{*}=$ bemakna (nilai $\mathrm{p}<0,05$ )

frekuensi makanan selingan, energi makanan selingan, dan karbohidrat makanan selingan terhadap kejadian overweight. Hasil analisis multivariat menunjukkan bahwa sarapan pagi dan karbohidrat makanan selingan berhubungan bermakna $(\mathrm{p}<0,05)$ dengan kejadian overweight.
Model 2 untuk mengetahui hubungan variabel sarapan pagi dan karbohidrat makanan selingan terhadap kejadian overweight. Hasil analisis multivariat menunjukkan bahwa ada hubungan sarapan pagi dan karbohidrat makanan selingan $(\mathrm{p}<0,05)$ dengan kejadian 
Tabel 6. Analisis multivariat sarapan pagi dan makanan selingan dengan kejadian overweight pada remaja

\begin{tabular}{llccc}
\hline \multirow{2}{*}{ Model } & \multicolumn{1}{c}{ Variabel } & \multicolumn{3}{c}{ Kelompok kasus kontrol } \\
\cline { 3 - 4 } & & OR & p & $\mathbf{R}^{2}$ \\
\hline Model 1 & Sarapan pagi & 3,60 & $0,002^{*}$ & 0,098 \\
& Frekuensi makanan selingan & 1,40 & 0,450 & \\
& Energi makanan selingan & 0,70 & 0,523 & \\
& Karbohidrat makanan selingan & 5,50 & $0,002^{*}$ & \\
\multirow{2}{*}{ Model 2 } & Sarapan pagi & 3,59 & $0,002^{*}$ & 0,095 \\
& Karbohidrat makanan selingan & 5,05 & $0,000^{*}$ & \\
\multirow{2}{*}{ Model 3 } & Sarapan pagi & 4,03 & $0,001^{*}$ & 0,124 \\
& Karbohidrat makanan selingan & 4,19 & $0,001^{*}$ & \\
& Aktivitas fisik & 2,40 & $0,005^{*}$ & \\
\hline
\end{tabular}

Keterangan: * nilai $\mathrm{p}<0,05$ ada hubungan variabel dependen dengan variabel independen

overweight. Model 2 ini menunjukkan bahwa remaja tidak rutin sarapan pagi berisiko 3,6 kali menjadi overweight dibandingkan remaja yang rutin sarapan pagi setelah dikontrol dengan karbohidrat dari makanan selingan. Remaja dengan konsumsi tinggi karbohidrat dari makanan selingan berisiko 5 kali menjadi overweight dibandingkan remaja dengan konsumsi tidak tinggi karbohidrat dari makanan selingan setelah dikontrol dengan sarapan pagi.

Model 3 untuk mengetahui hubungan variabel sarapan pagi dan karbohidrat makanan selingan terhadap kejadian overweight dengan dikontrol variabel aktivitas fisik. Hasil analisis multivariat menunjukkan bahwa ada hubungan sarapan pagi, karbohidrat makanan selingan, dan aktivitas fisik dengan kejadian overweight. Model 3 menunjukkan bahwa remaja yang tidak rutin sarapan pagi berisiko 4 kali menjadi overweight dibandingkan remaja yang rutin sarapan pagi dengan dikontrol oleh karbohidrat dari makanan selingan dan aktivitas fisik. Remaja dengan konsumsi tinggi karbohidrat dari makanan selingan berisiko 4,2 kali menjadi overweight dibandingkan remaja dengan konsumsi tidak tinggi karbohidrat dari makanan selingan setelah dikontrol dengan sarapan pagi dan aktivitas fisik.

\section{BAHASAN}

Hasil skrining yang dilakukan terhadap enam SMA di Kota Pontianak diperoleh prevalensi overweight sebesar $16,8 \%$. Prevalensi ini lebih besar apabila dibandingkan dengan prevalensi overweight pada tahun 2005 untuk kelompok usia di atas 15 tahun di provinsi Kalimantan Barat yaitu sebesar 13\%. Berdasarkan data Riskesdas tahun 2010 menunjukkan bahwa prevalensi overweight untuk kelompok usia 16-18 tahun sebesar 1,4\% dan usia di atas 18 tahun sebesar 10\% (3). Berdasarkan angka prevalensi tersebut dapat menjadi suatu indikator bahwa prevalensi overweight telah mengalami peningkatan khususnya di Kota Pontianak.

Peningkatan prevalensi overweight pada anakanak dan remaja telah menjadi masalah utama kesehatan masyarakat tidak hanya di negara-negara industri (19) tetapi juga telah menjadi masalah kesehatan masyarakat di negara-negara berkembang (21). Overweight dan obesitas pada masa remaja berpengaruh terhadap kejadian obesitas pada masa dewasa (4). Overweight dan obesitas pada masa remaja juga berpengaruh terhadap timbulnya berbagai penyakit degeneratif saat dewasa, yaitu remaja overweight mempunyai risiko 8,5 kali menderita hipertensi saat dewasa (22). Remaja overweight juga berisiko 2,4 kali meningkatnya total kolesterol di atas $240 \mathrm{mg} / \mathrm{dl}$, berisiko 3 kali meningkatnya LDL di atas $160 \mathrm{mg} / \mathrm{dl}$, dan berisiko 8 kali meningkatnya risiko penurunan HDL di bawah $35 \mathrm{mg} /$ dl di saat usia dewasa. Remaja penderita sindrom metabolik, sebesar $30-50 \%$ adalah remaja overweight (23).

Kegiatan pencegahan dan penanggulangan overweight yang dapat dilakukan khususnya pada anak sekolah meliputi promosi, penemuan, dan tatalaksana kasus yang dalam pelaksanaannya melibatkan anak, orang tua, guru, komite sekolah, dan stakeholder. Tujuan pencegahan adalah terjadinya perubahan pola dan perilaku makan yaitu meningkatkan kebiasaan konsumsi 
buah dan sayur, mengurangi konsumsi makanan dan minuman manis, mengurangi konsumsi makanan tinggi energi dan lemak, mengurangi konsumsi junk food, serta peningkatan aktivitas fisik, dan mengurangi sedentary lifestyle (24).

Hasil analisis menunjukkan bahwa ada hubungan antara sarapan pagi dengan kejadian overweight. Remaja yang tidak rutin sarapan pagi mempunyai risiko 3,1 kali untuk menjadi overweight dibandingkan remaja yang rutin sarapan pagi. Hal ini sesuai dengan penelitian sebelumnya yang menunjukkan bahwa anak-anak yang rutin mengonsumsi sarapan pagi di rumah mempunyai rerata IMT yang lebih rendah dibandingkan anak-anak yang tidak sarapan pagi (8). Orang yang tidak sarapan pagi mempunyai IMT lebih tinggi dibandingkan dengan orang yang sarapan pagi karena orang yang tidak sarapan pagi cenderung menjadi tidak seimbang pola makannya, seperti mengonsumsi makan siang dalam jumlah besar (25).

Beberapa penelitian menunjukkan bahwa anakanak dan remaja yang mengonsumsi sarapan pagi mempunyai jumlah asupan energi yang baik, yang tidak dapat dikompensasikan apabila tidak sarapan pagi. Penelitian sebelumnya menunjukkan bahwa anak-anak dan remaja yang tidak sarapan pagi, jarang mengonsumsi buah dan sayuran dan cenderung mengonsumsi makanan jajanan yang tidak sehat saat dalam perjalanan di sekolah ataupun saat di sekolah (8). Penelitian pada anak sekolah di Hong Kong juga menyimpulkan bahwa tidak sarapan pagi berhubungan dengan kejadian overweight dan obesitas, perilaku makan yang kurang sehat termasuk meningkatnya frekuensi makan junk food, kurang mengonsumsi buah dan sayuran serta susu. Orang yang tidak sarapan pagi juga cenderung untuk tidak makan siang, jarang mengikuti kegiatan yang berkaitan dengan aktivitas fisik, dan lebih sering menonton televisi (26).

Rerata asupan energi sarapan pagi kelompok overweight lebih kecil $(208,57 \pm 233,53 \mathrm{kkal})$ dibandingkan kelompok tidak overweight $(299,7 \pm 230,67 \mathrm{kkal})$. Kelompok tidak overweight cenderung mempunyai rerata asupan energi, lemak, dan karbohidrat dari sarapan pagi lebih tinggi dibandingkan kelompok overweight. Walaupun rerata asupan energi untuk kelompok tidak overweight lebih besar bila dibandingkan dengan kelompok overweight, tetapi rerata asupan energi sarapan pagi pada kelompok overweight maupun kelompok tidak overweight belum memenuhi kebutuhan energi sarapan pagi (20-25\% dari total asupan energi). Hal ini menunjukkan bahwa masih kurangnya remaja mendapatkan asupan energi dari sarapan pagi. Meskipun beberapa penelitian menunjukkan hasil yang berbeda, tetapi konsumsi sarapan pagi berhubungan dengan berat badan yang ideal pada anak dan remaja, bermanfaat pada fungsi kognitif terutama pada daya ingat, prestasi akademik, jumlah kehadiran di sekolah, dan psikososial (27). Anak-anak dan remaja yang tidak sarapan pagi mengalami penurunan asupan mikro nutrisi dibandingkan dengan anak-anak dan remaja yang rutin sarapan pagi dan rendahnya asupan ini tidak dapat digantikan dengan waktu makan yang lain (28).

Frekuensi mengonsumsi makanan selingan lebih dari dua kali dalam sehari lebih banyak ditemukan pada kelompok overweight ( $62 \%$ ) dibandingkan kelompok tidak overweight (46\%). Hal ini menunjukkan bahwa remaja overweight lebih cenderung mengonsumsi makanan selingan lebih dari dua kali dalam sehari dibandingkan remaja yang tidak overweight. Faktor penyebab lain remaja overweight lebih banyak mengonsumsi makanan selingan lebih dari dua kali dalam sehari adalah jumlah uang saku yang diterima oleh kelompok overweight lebih banyak dibandingkan kelompok yang tidak overweight. Rerata uang saku kelompok overweight sebesar $\mathrm{Rp}$ 16.140,- sedangkan kelompok tidak overweight sebesar Rp 11.950,-. Sebagian besar subjek pada kelompok overweight dan kelompok tidak overweight menggunakan uang saku untuk membeli makanan dan minuman sehingga jika jenis makanan jajanan yang dikonsumsi sama maka kelompok overweight cenderung lebih banyak mengonsumsi makanan jajanan dibandingkan kelompok tidak overweight.

Lebih lanjut, rerata asupan energi makanan selingan kelompok overweight $(440,9 \pm 304,8 \mathrm{kkal})$ lebih besar dibandingkan kelompok tidak overweight $(400,5 \pm 303,3 \mathrm{kkal})$. Hal ini terkait dengan tingginya frekuensi konsumsi makanan selingan pada kelompok overweight dibandingkan kelompok tidak overweight. Makanan selingan lebih banyak diperoleh dari makanan jajanan dibandingkan buatan rumah sehingga ada 
kecenderungan mengonsumsi makanan yang kurang sehat. Sebagian besar subjek membeli makanan jajanan di kantin sekolah pada waktu siang hari. Hal ini menunjukkan bahwa remaja cenderung mengonsumsi makanan selingan pada saat jam istirahat di sekolahnya. Menurut hasil penelitian sebelumnya, disimpulkan bahwa anak yang tidak sarapan pagi berhubungan bermakna dengan perilaku makan yang tidak sehat, yaitu adanya kecenderungan bahwa anak yang tidak sarapan akan membeli makanan dalam perjalanan ke sekolah atau di kantin sekolah dua kali lebih sering dibandingkan dengan anak yang sarapan pagi (8).

Sementara itu, hasil penelitian ini juga membuktikan bahwa frekuensi makanan selingan berhubungan bermakna dengan kejadian overweight yaitu remaja yang mengonsumsi makanan selingan lebih dari dua kali dalam sehari berisiko 1,9 kali menjadi overweight dibandingkan remaja yang mengonsumsi makanan selingan kurang atau sama dengan dua kali dalam sehari. Lebih lanjut, energi makanan selingan mempunyai hubungan bermakna dengan kejadian overweight. Remaja dengan konsumsi makanan selingan yang berenergi tinggi akan berisiko 2,1 kali menjadi overweight dibandingkan remaja dengan konsumsi makanan selingan yang tidak tinggi energi.

Selain itu, remaja dengan konsumsi makanan selingan yang tinggi karbohidrat akan berisiko 4,5 kali menjadi overweight dibandingkan remaja dengan konsumsi makanan selingan yang tidak tinggi karbohidrat. Hal ini menunjukkan bahwa energi dan karbohidrat makanan selingan mempunyai pengaruh terhadap kejadian overweight. Berbeda dengan hasil penelitian sebelumnya yang menyatakan bahwa prevalensi overweight dan obesitas abdominal menurun dengan meningkatnya frekuensi makanan selingan dan meningkatnya persentase energi makanan selingan. Hal ini dimungkinkan apabila makanan selingan yang dikonsumsi meningkatkan kualitas makanan hariannya, meningkatkan asupan buah, sayuran, biji-bijian (whole grain), dan serat sehingga dapat mempertahankan rasa kenyang dan menurunkan risiko overweight (7).

Beberapa variabel yang berhubungan dengan kejadian overweight dan dimasukkan dalam analisis multivariat yaitu sarapan pagi, frekuensi makanan selingan, energi makanan selingan, karbohidrat makanan selingan serta tingkat aktivitas. Hasilnya menunjukkan bahwa variabel yang mempunyai hubungan bermakna terhadap kejadian overweight adalah sarapan pagi, karbohidrat makanan selingan, dan aktivitas fisik. Berdasarkan hasil ini dapat disimpulkan bahwa untuk mengatasi masalah overweight pada remaja, selain diperlukan perilaku rutin sarapan pagi, juga harus diimbangi dengan tidak mengonsumsi makanan selingan yang mengandung tinggi karbohidrat serta meningkatkan aktivitas fisik.

\section{SIMPULAN DAN SARAN}

Prevalensi overweight pada remaja SMA di Kota Pontianak sebesar $16,8 \%$. Sarapan pagi berhubungan dengan kejadian overweight pada remaja dan sarapan pagi yang tidak rutin merupakan faktor risiko terhadap kejadian overweight pada remaja. Makanan selingan tidak berhubungan bermakna dengan kejadian overweight pada remaja. Namun, frekuensi makanan selingan berhubungan bermakna dengan kejadian overweight pada remaja. Frekuensi makanan selingan lebih dari dua kali dalam sehari serta makanan selingan yang tinggi energi dan karbohidrat merupakan faktor risiko terhadap kejadian overweight. Aktivitas fisik juga berhubungan bermakna dengan kejadian overweight dan aktivitas ringan menjadi faktor risiko terhadap kejadian overweight.

Berdasarkan hasil penelitian ini maka disarankan bagi remaja untuk sarapan pagi sebelum memulai aktivitas sehari-hari. Jumlah asupan sarapan pagi sebaiknya sebesar 20-25\% dari AKG dan seimbang nilai gizinya. Sebaiknya remaja tidak mengonsumsi makanan selingan yang tinggi energi dan tinggi karbohidrat serta meningkatkan aktivitas fisik.

\section{RUJUKAN}

1. WHO. Obesity and overweight. [series online] 2012 [cited 2012 Des 6]. Available from: URL: http.//www.who.int/ mediacentre/factsheets/fs $311 / \mathrm{en} /$ index.html

2. Depkes RI. Riset kesehatan dasar tahun 2007. Jakarta: Balai Penelitian dan Pengembangan Kesehatan Departemen Kesehatan Republik Indonesia; 2008.

3. Kemenkes RI. Riset kesehatan dasar tahun 2010. Jakarta: Badan Penelitian dan Pengembangan Kesehatan Kementerian Kesehatan RI; 2010.

4. Guo SS, Wu W, Chumlea WC, Roche AF. Predicting overweight and obesity in adulthood from body mass 
index values in childhood and adolescence. Am J Clin Nutr 2002;76(3):653-8.

5. Raman RP. Obesity and health risks. J Am Coll Nutr 2002;21(2):134S-9S.

6. St-Onge MP, Keller KL, Heymsfield SB. Change in childhood food consumption patterns: a cause for concern in light of increasing body weight. Am J Clin Nutr 2003;78(6):1068-73.

7. Keast DR, Nicklas TA, O'Neil CE. Snacking is associated with reduced risk of overweight and reduced abdominal obesity in adolescents: National Health and Nutrition Examination Survey (NHANES) 1999-2004. Am J Clin Nutr 2010;92(2):428-35.

8. Utter J, Scragg R, Mhurchu CN, Schaaf D. At-home breakfast consumption among New Zealand children: association with body mass index and related nutrition behaviors. J Am Diet Assoc 2007;107(4):570-6.

9. McCrory MA, Campbell WW. Effect of eating frequency, snacking, and breakfast skipping on energy regulation: symposium overview. J Nutr 2011;141(1):144-7

10. Pereira MA, Erickson E, McKee P, Schrankler K, Raatz SK, Lytle LA, Pellegrini AD. Breakfast frequency and quality may affect glycemia and appetite in adults and children. J Nutr 2011;141(1):163-8.

11. Lemeshow S, Hosmer DW, Klar J, Lwanga SK. Besar sampel dalam penelitian kesehatan. Yogyakarta: Gadjah Mada University Press; 1999.

12. Wahyuni, Winda. Perbedaan asupan energi sarapan pagi dan asupan energi jajan berdasarkan status gizi siswa SMP [Tesis]. Yogyakarta: UGM; 2010.

13. Mahdiah, Hadi H, Susetyowati. Prevalensi obesitas dan hubungan konsumsi fast food dengan kejadian obesitas pada remaja SLTP kota dan desa di Daerah Istimewa Yogyakarta. Jurnal Gizi Klinik Indonesia 2004;1(2):7785.

14. Biro FM, Wien M. Childhood obesity and adult morbidities. Am J Clin Nutr 2010;91(5):1499S-505S.

15. Savige G, Macfarlane A, Ball K, Worsley A, Crawford D. Snacking behaviours of adolescents and their association with skipping meals. Int J Behav Nutr Phys Act 2007;4:36.
16. Kemenkes RI. Makanan sehat anak sekolah. JIPG 2011;XVII(2).

17. Soetardjo, Susirah. Gizi usia remaja. Gizi seimbang dalam daur kehidupan. Jakarta: PT Gramedia Pustaka Utama; 2011.

18. Finkelstein EA, Strombotne KL. The economics of obesity. Am J Clin Nutr 2010;91(5):1520S-4S.

19. Veugelers PJ, Fitzgerald AL. Prevalence of and risk factor for childhood overweight and obesity. CMAJ 2005;173(6):607-13.

20. Dehghan M, Akhtar-Danesh N, Merchant AT. Childhood obesity, prevalence and prevention. Nutr J 2005;4:24.

21. Kosti RI, Panagiotakos DB. The epidemic of obesity in children and adolescence in the world. Cent Eur J Publ Health 2006;14(4):151-9.

22. Must A, Strauss RS. Risks and consequences of childhood and adolescence obesity. Int J Obes Relat Metab Disord 1999;23(Suppl 2):S2-11.

23. Daniels SR, Arnett DK, Eckel RH, Gidding SS, Hayman LL, Kumanyika S, Robinson TN, Scott BJ, St Jeor S, Williams CL. Overweight in children and adolescents: pathophysiology, consequences, prevention, and treatment. Circulation 2005;111(15):1999-2012.

24. Kemenkes RI. Pedoman pencegahan dan penanggulangan kegemukan dan obesitas pada anak sekolah. Jakarta: Direktorat Jendral Bina Gizi dan Kesehatan Ibu dan Anak; 2012.

25. Cho S, Dietrich M, Brown CJ, Clark CA, Block G. The effect of breakfast type on total daily energy intake and body mass index: results from the Third National Health and Nutrition Examination Survey (NHANES III). J Am Coll Nutr 2003;22(4):296-302.

26. Tin SP, Ho SY, Mak KH, Wan KL, Lam TH. Lifestyle and socioeconomic correlates of breakfast skipping in Hong Kong primary 4 schoolchildren. Prev Med 2011;52(3-4):250-3.

27. Rampersaud GC, Pereira MA, Girard BL, Adams J, Metzl JD. Breakfast habits, nutritional status, body weight and academic performance in children and adolescents. J Am Diet Assoc 2005;105(5):743-60.

28. Affenito. Breakfast: a missed opportunity. Research editorial. West Hartford: American Dietetic Association; 2007. 